\title{
Challenges of Symbiotic Relationship of Global Warming, National Interest Ideology of Nation States and the Project of a Low Carbon Society: An African Perspective
}

\author{
Dokun Oyeshola*, Ms Adaora Osondu \\ Department of International Relations, Obafemi Awolowo University, Ile-Ife, Nigeria \\ *Corresponding author: doyeshola@oauife.edu.ng
}

Received October 29, 2013; Revised December 27, 2013; Accepted January 17, 2014

\begin{abstract}
The memory is fresh and the grief due to the devastating impact of climate change on humanity during the past decade is still raw in the psychic of international community. Specifically, on December 26, 2004 tsunami swept through Asia. In Indonesia it killed over 130,000 people while at least 37,000 went missing and about 500,000 people were made homeless. Sri Lanka lost more than 31,000 lives while 100,000 homes were damaged along with crops and fishing boats and more than 400,000 people lost their jobs. It is this dynamic, overwhelming, destructive capacity associated with climate change as manifested in hurricanes, tsunamis, quakes and floods that makes it a special and different security problem. Any delay in addressing the problem of climate change promptly and radically too may mean that the planet earth may soon be irrevocably damaged and prevented from carrying out its sustaining role for humanity. This has challenged the global community, NGOs and concerned individuals to call for a low carbon society and organize conferences and formulate treaties and environment policies, and laws. All these are carried out within the context of national interest ideology. Consequently, climate change is still a serious challenge to human security. Why has global warming/climate change not been checkmated before now despite the huge world's resources inclusive of its technology? It is this challenge that this paper is interrogating in the face of the global environmental goal of a low carbon society and environmental wholeness from an African perspective.
\end{abstract}

Keywords: global warming, climate change, national interest ideology, sustainable development, low carbon society, rule of law, human rights, human development

Cite This Article: Dokun Oyeshola, and Ms Adaora Osondu, "Challenges of Symbiotic Relationship of Global Warming, National Interest Ideology of Nation States and the Project of a Low Carbon Society: An African Perspective.” Applied Ecology and Environmental Sciences, vol. 2, no. 1 (2014): 8-19. doi: 10.12691/aees-2-1-2.

\section{Introduction}

Contemporary international system is characterized by the following namely; the rise in the number and types of states; the great potential for destruction by those who possess weapons of mass destruction; increased vulnerability of states to external intrusions, including subversion, terrorism, economic pressures and military conquest; rising importance of non-state actors like multinationals, international interest groups and political parties transcending national frontiers; the increasing power of non-European states like Russia, China, emerging industrialized states; and the great degree of dependence and interdependence between and among all types of actors in international system [1]. Similarly it may be observed that international community is gradually moving towards a transparent world especially through its promotion of democratic principles and good governance. Also increasing philanthropic gestures of individuals are not only increasing but gradually moving away from their contribution being made at the end of life of individuals to through their entire lives. Fulfillment of social responsibility of many organizations to their host communities especially in many African countries is becoming apparent. These organizations contribute to the promotion of sport, education by way of giving scholarship and building of infrastructure and capacity building of citizens. Furthermore, human creativity is leading to good life unfortunate bad use of technology notwithstanding. Arguably, these emerging tendencies are reinforcing the search for solutions the challenges global warming poses by international community adopting the Project of a Low Carbon Society. It is within this context that this paper's topic is discussed. However, this context may not be meaningful without situation it in a wider global context.

\subsection{Contextual Background}

Arguably, the contemporary states system dates back to the Treaty of Westphalia of 1648 that brought the thirty years war in Europe to an end. The Treaty recognized the 
major European units at the time (the Holy Roman Empire) The German kingdoms, the Netherlands, Spain, France, and the Dutch Republic as sovereign states. They enjoyed the right to determine their own official religions, and citizens who did not practice the official religion were given the freedom of religion with some restrictions. The concept of sovereignty included territorial integrity, non intervention, and political self determination. By granting independence to all dependencies, and with the collapse of the empire, all former units were regarded as politically equal to one another and not answerable to any superior authority. Before relations between the units in the above systems were conducted in the name of the Pope or Monarchs, Dukes or Duchesses, as the case may be [2].

However, the broad agreement among scholars regarding the Western origin of the international political system does not imply that there were no other systems before the 1648. There were several systems such as the Greek City States, the Imperial Chinese System, the Indian State System, the Roman and Byzantine Empires, the Mali and Songhai Empires in West Africa, to mention a few.

By the nineteenth century, States have become the primary institutional agents in an interstate western system of relations [3]. According to Frankel [4], international system consists of a number of units that interact. In further explanation Frankel maintained that 'it is clear that these units conduct their relations not in a vacuum but within a broader system which evolves its own structure, norms and behaviors.' What is clear is that international system has units (states and non-state actors such as multinational corporations, international organizations, and even individuals) which are in constant interaction, with rules and norms of behaviors.

Contemporary international system is known to be an artificially originated system by states and is highly voluntaristic, that is, its members join it out of their own free will to constitute a system, and this is what is obtainable in United Nations, African Union, European Union etc. Furthermore, the international system is known to be highly decentralized. There is no central administrative, political or military authority in charge of the system. Although the United Nations comes close to an international authority, it has shortcomings. Its decisions, even those of the Security Council can be ignored by states or thwarted by its members. For instance, China and Russia have continued to challenge the decision of the United Nations Security Council with regards to intervention in crisis ridden states. This was seen in the case of Sudan, when China and Russia abstained from voting in favor of UN intervention and sanctions in Sudan during the Darfur conflict. In the on-going crisis in Syria, China and Russia have vetoed against United Nations US support for military intervention in Syria. It is clear that there is no central authority in the system as each state becomes an 'authority' on its own. A consequence of the decentralized nature of the international system is that both state and non-state actors are majorly guided by their perception of their self interest in interactions with other units in the system.

Arguably, international system is structured with its anarchical characteristics. The structure reflects a building or a motor car in its framework and the way in which the various constituent parts fit together. As a socio-political entity, many significant units arise as a consequence of a myriad of human interactions which both constitute and reinforce. This reality serves to constrain and channel behavior and so prescribe the choice open to actors in international system.

The organizing principle of the international system is anarchical as opposed to the hierarchy one might expect to find in municipal/domestic system or arrangement of a nation state. This has a very important consequence for the second element of structure which is the differentiation of the units. The logic of anarchy and the absence of an ordered hierarchy mean that each unit must compete with its counterparts and fulfill equivalent functions, leading inevitably to a situation in which they all resemble each other.

The third defining element of structure is the distribution of capacities across units. This is comparable with the constituents of national power as listed by Morgenthau [5] as geographical position, natural resources and technological endowments, industrial/military capability and the intangibles of national morale and character and the quality of government and diplomacy.

It is in this anarchical and complex international system that the planet Earth, a common heritage and a special gift to humanity finds itself. Whatever happens to the planet Earth for instance, global warming, affects all its inhabitants either for good or bad. The uncompromising challenge of low carbon society finds itself in the contemporary international system within the interconnectedness of actors in the system, national ideology orientation of nation states, international law and morality/ethics. Similarly, the problematic of earth's alarming population growth, its inability to adequately and equitably sustain its population and absorb its waste [6] is equally situated.

The contemporary intercourse on international system has reinstated real politic. There are now strong linkages among the variables of politics and economics, international law and national state ideology. This is because international economic relations in and of themselves constitute political relations while international politics is the 'patterns of political interactions between and among states' which involves goal-seeking behavior and a process of deciding who gets what, when and how'. The subject of international economic relations may also be viewed as the management of conflict and cooperation in the absence of government.

As with all international political interactions, economic interaction ranges from conflicts to cooperation. Some economic relations lead to high levels of conflict because wealth is an important goal of groups in international politics and the pursuit of wealth in the presence of scares resources leads to conflict especially over access to markets, the control of raw materials and the means of production. Such conflict often is linked to conflict over power and sovereignty. Other times, much international economic interactions, however, have a high level of cooperation. Many states share the goals of a stable monetary system, expanding trade relations and rising production although they differ over the means of achieving these ends. Some favor fixed exchange rates whereas others prefer a float. Some advocate tariff reductions on textiles whereas others forcefully oppose 
them. Some consider multinational cooperation to be a vital road to economic growth whereas others believe that they perpetuate underdevelopment [7].

In the context of law and morality and especially under Anglo-American legal thought, municipal/domestic law is taken to be the paradigm of how a legal system should work to uphold the rights of citizenry. Legal rules are promulgated and updated by a legislature or by common law courts subject to legislative revision. Courts authoritatively resolve ambiguities and uncertainties about the application of law in particular cases. The individuals to whom laws are addressed have an obligation to obey legitimate lawmaking authorities, and express their discontent when legal rules stand in the way of their interests or are imposed without their consent. In cases of disobedience, an executive enforcement authority possessing a monopoly over the use of legitimate force stands ready to coerce compliance.

Unlike domestic law, international law seems different and deficient along each of these dimensions. International law has no centralized legislature or hierarchical court system authorized to create, revise or specify the application of legal norms and as a result is said to suffer from irremediable uncertainty and political contestation. Whereas international law is a voluntary system that obligates only states that have consented to be bound and thus generally lacks the power to impose obligations on states against their interests. As a result, the content of international law often reflects the interests of powerful states. And to the extent that international law diverges from those interests, powerful states often interpret it away or ignore it. They are able to do so because the international legal system lacks a super-state enforcement authority capable of coercing recalcitrant states to comply as was evident in the US-Iraqi war of 2003. This weakness and loophole notwithstanding the importance and relevance of international law in international system must be appreciated and affirmed.

Often, necessity and mutual consent are the operating forces in the creation and enforcement of any law. This is why morality plays a vital role on the conduct of states as well as international community because the notion of moral behavior may be linked to religious beliefs, secular ideologies or philosophies and the standard of equity (that is, what is fair, and as well the practice of a society, that is, what a society considers moral behavior. Sometimes this becomes law). Legal standards most times are adopted by a society as moral standards. Therefore, international system must necessarily incorporate ethics/morality into its system.

In the late 1960s the issue of global warming started to engage the attention of some scientists who alerted the world that the global temperature is rising more than usual and in an unidirectional and irreversible manner. They contended that it was not the usual temperature variation. The world received this alert with a lot of skepticism. However, as the study of the world temperature continued, the alert started to generate serious concerns as more and more scientists started to point to evidence of the phenomenon. The situation was not that clear or generally accepted when the first global earth summit of 1972 at Stockholm in Sweden was convened. The conference was on the environment. During the conference not much consensus on issues was arrived at. Thereafter and for more than a decade after the conference the US Environmental Protection Agency was still searching for the trend in gas emission [8]. Indeed, up to the 1990s, American Congress was still probing the uncertainties surrounding climate change [9]. However, the 1972 summit established the United Nations Environmental Program (UNEP) located in Nairobi, Kenya and mandated it to coordinate researches and results of further environmental studies along the line of global warming and ozone layer depletion [10]. Accordingly, UNEP started to inform the world on environmental issues through its Bulletin titled “Our Planet” [11].

Further summits were held and protocols, conventions and treaties were ratified. At last, the world has now accepted that global warming is a reality and that the climate of the planet is undergoing a change towards hotter and drier conditions. Also, a conclusion was reached namely that human activities that have escalated the emission of greenhouse gases, particularly carbon dioxide $\left(\mathrm{CO}_{2}\right)$ are principal factors responsible for the global warming. Accordingly, it is agreed that the best way to freeze the process of global warming and climate change or at least reduce its rate of progression is by taking remediation measures such as the reduction in carbon emission, the reduction in carbon accumulation through the provision of carbon sinks, thereby achieving a low carbon society, as well as embarking on adaptation measures to reduce the disaster that the effects of climate change and global warming may bring about. These have to be done in the context of contemporary international relationships.

Furthermore, through variety of its initiatives especially the Earth Summits, the international community has come to establish a symbiotic relationship among global warming, national interest and responsibility of nation states and the need to 'save' the planet. Accordingly, it has accepted and affirmed the need to reduce greenhouse gas (GHG) emissions by 50\% until 2050 in order to keep the change in global mean temperature within two degrees centigrade compared to preindustrial times. In order to achieve this target, it is imperative to develop low carbon societies (LCS) especially in the developing countries as they will account for more than half of the global population and GHG emissions by 2050.

\section{Objectives}

Any delay in addressing the problem of climate change promptly and radically too may mean that the planet earth may soon be irrevocably damaged and prevented from carrying out its sustaining role for humanity. This has challenged the global community, NGOs and concerned individuals to call for a low carbon society and organize conferences and formulate treaties and environment policies, and laws. All these are carried out within the context of national interest ideology. Consequently, climate change is still a serious challenge to human security. Why has global warming/climate change not been checkmated before now despite the huge world's resources inclusive of its technology? It is this challenge that this paper is interrogating in the face of the global environmental goal of a low carbon society and environmental wholeness from an African perspective. 


\section{Approach to the Study}

This paper starts with introduction and contextual background before stating the objectives of the paper. Discussion on the understanding the concept of low carbon society, and challenges imposed by the symbiotic relationships of global warming, national interest ideology and low carbon society from an African perspective followed. The paper concludes that the way forward to bring about a (global) Low Carbon Society is for the international community to unanimously address credibly and creatively the challenges of symbiotic relationships of national interest ideology, issue of putting human beings at the heart of political and socio-economic activities of global world and the project of low carbon society within the context of international law. Reform (democratization) of the Security Council is part of the solution. In other words there is a need for good governance even at the global level in order to control climate change and promote low carbon society. The sources of data collected are secondary and they are contextually analyzed.

\section{Discussion}

Before proceeding to discuss the challenges and way forward it is pertinent to shed light on what low carbon society is all about.

\subsection{Understanding Low Carbon Society}

The Ministry of Environment, Japan describes a LowCarbon Society (also known as a Carbon Neutral Society) to be a society that emits greenhouse gases only in the quantity which can be absorbed by nature. This implies creating and/or maintaining an economy, environment or society where the carbon emission is low, or drastically reduced through the replacement of fossil fuel burning by the use of renewable and cleaner energy, that is, a decarbonized society. This way a green economy is achieved through sensibly minimizing carbon dioxide $\left(\mathrm{CO}_{2}\right)$ emissions through energy efficiency and/or low-carbon technologies. Paths to achieve a low carbon society span diverse issues such as low-carbon agriculture and food, low-carbon buildings and cities, low-carbon energy, and low-carbon water among others.

However, the project of Low Carbon Society cannot meaningfully be discussed and appreciated without situating it within the context of its emergence. Logically therefore, it must find its context in global warming with its treating characteristics and attendant devastating consequences.

Global warming may be described as the rise in the average temperature of Earth's atmosphere and oceans since the late 19th century and its projected continuation. Since the early 20th century, Earth's mean surface temperature has increased by about $0.8^{\circ} \mathrm{C}\left(1.4^{\circ} \mathrm{F}\right)$, with about two-thirds of the increase occurring since 1980 . Warming of the climate system is unequivocal and scientists are more than $90 \%$ certain that it is primarily caused by increasing concentrations of greenhouse gases produced by human activities such as the burning of fossil fuels and deforestation. These findings are recognized by the national science academies of all major industrialized nations [12].
The global atmospheric concentration of carbon dioxide $\left(\mathrm{CO}_{2}\right)$ has increased from a pre-industrial value of about 280 ppm (parts per million) to 379 ppm in 2005 while preindustrial value of methane $\left(\mathrm{CH}_{4}\right)$ was $715 \mathrm{ppb}$ (part per billion) has increased to $1774 \mathrm{ppb}$ in 2005. The atmospheric concentration of Nitrous oxide (NOx) jumped from pre-industrial value of about $270 \mathrm{ppb}$ to $319 \mathrm{ppb}$ in 2005 [13]. As the volume of greenhouse gases like $\left(\mathrm{CO}_{2}\right)$, Carbon Monoxide (CO), Methane $\left(\mathrm{CH}_{4}\right)$, Nitrous oxide $\left(\mathrm{N}_{2} \mathrm{O}\right)$, and Chlorofluorocarbons (CFSs) increases, the temperature close to the earth's surface rise gradually. One of the principal consequences of the changing chemistry of the atmosphere is the depletion of ozone layer.

It has been predicted that more people will get sick or die from heat stress, due not only to hotter days but more importantly to warmer nights (giving the sufferer less relief) when the world becomes warmer. Frequent and intense heat waves will continue to contribute to this trend. At the same time, there will be some decreases in the number of cold-related deaths. Diseases such as malaria now found in the tropics and transmitted by mosquitoes and other animal host move into regions formerly too cold for them. Other tropical diseases may spread similarly, including dengue fever, yellow fever and encephalitis. Also rising incidence of allergies and respiratory diseases as warmer air grows more charged with pollutants, mould spores and pollen [14].

Other likely effects of the warming include a more frequent occurrence of extreme weather events including heat waves, droughts and heavy rainfall, ocean acidification and species extinctions due to shifting temperature regimes. Effects significant to humans include the threat to food security from decreasing crop yields and the loss of habitat from inundation [15].

Warming temperatures are already causing significant changes to mountain glaciers around the world, ice sheets in Greenland and the Antarctica, and polar sea ice in the arctic from Europe to Asia to North America. Mountain glaciers have receded over the $20^{\text {th }}$ century, and melting of ice may accelerate the place of global warming in what is known as a feedback process. Because ice reflects sunlight back out of space, it has cooling effect. Water and land, which are darker than ice, absorb and retain more heat.

Glaciers on Kilimanjaro have lost $82 \%$ of their ice since 1912 and are estimated to be gone completely by 2020 . Glaciers in the lofty Himalayas of Asia are melting at a rate of 9 to $15 \mathrm{~m}$ per year. Annual runoff from these glaciers feeds major rivers such as the Ganges, Yangtze, and Mekong.

The area covered by sea ice during summer has declined by 15 to 20 percent in the last 40 years and is projected to disappear almost completely in the late $21^{\text {st }}$ century. Many such as polar bears, seals and walrus, depend on sea ice for survival. The rapid loss of ice in glaciers worldwide, and makes a significant contribution to observed sea level rise. Melting of Greenland, ice sheets, which could rise sea level by $7 \mathrm{~m}$ (23ft) if is melted completely, is also accelerating. The area that is experiencing at least some melting increased by $16 \%$ from 1979 to 2002, and scientists estimate that warming of more than a few degrees Celsius could wide spread a possibly unstoppable melting, leading to significant sea level rise. 
Fresh water flowing from melting Arctic ice into the North Atlantic Ocean could disrupt ocean circulation patterns, which have significant influence on global climate. According to scientists' projections, a collapse of ocean circulation pattern is unlikely to occur by 2100 . However, scientists do expect there to be a weakening and slowing of thermo line circulation, also known as the ocean conveyor belt. In addition, a disruption of surface circulation pattern is North Atlantic, known collectively as the Gulf Stream could lead to cooling in Europe.

In Antarctica the situation is somehow different from that of the Arctic. The Antarctica peninsula, the "tail" of land reaching towards South America, has experienced dramatic warming at a rate several times the average over the past 50 years. However, other parts of Antarctica have not shown similar trends, with some areas warming and some areas cooling. Overall, Antarctica is estimated to be warming at about the global average rate. Unlike the arctic there has been clear trend in sea ice. In the Antarctica peninsula, however, ten floating ice shelves have lost more than 14,000 sq. $\mathrm{km}(5,400 \mathrm{sq} \mathrm{ml})$ of ice, and probably have not been at such a low level in the past 10,000 years. As in Greenland, scientist estimates that warming of more than a few degrees Celsius could lead to wide spread melting of the West Antarctica ice sheets. This melting alone would raise sea level by as much as $5 \mathrm{~m}$ (16ft).

Many of the seas and oceans have been seriously degraded in recent decades [16]. These oceans contain not only most of the planet's water but also a very diverse range of living organisms. About 300,000 marine species have been identified, but it is commonly held by marine scientists that there is at least double that amount of species. It will be tragic to think that much of this marine life may be destroyed long before some of them are even identified. Human activities have led to other manifestations of environmental degradation creating pollution of various types, wastes (toxic, industrial, domestic, solid), acid rain, desertification, deforestation, ozone layer depletion and erosion [17].

The complex ecosystem may take centuries to form but can be destroyed by human mismanagement in just a few years. If this happens, the ecosystem that supports the Earth will collapse and humanity will perish in the process. This is a devastating implication. It is within this reality of the possibility of total destruction of the Earth that the various initiatives of treaties, conventions, protocols, summits, and establishment of institutions and agencies were undertaken to address global warming.

Proposed policy responses include mitigation by emissions reduction, adaptation to its effects, and possible future geo-engineering. Most countries are parties to the United Nations Framework Convention on Climate Change (UNFCCC), whose ultimate objective is to prevent dangerous anthropogenic (i.e., human-induced) climate change. Parties to the UNFCCC have adopted a range of policies designed to reduce greenhouse gas emissions and to assist in adaptation to global warming. Parties to the UNFCCC have agreed that deep cuts in emissions are required and that future global warming should be limited to below $2.0^{\circ} \mathrm{C}\left(3.6^{\circ} \mathrm{F}\right)$ relative to the pre-industrial level. Reports published in 2011 by the United Nations Environment Programme and the International Energy Agency suggest that efforts as of the early 21st century to reduce emissions may be inadequate to meet the UNFCCC's $2{ }^{\circ} \mathrm{C}$ target [18].

Among others, these initiatives gave rise to development paradigm shift of philosophy of sustainable development. The sustainable development paradigm shift has been around since the 1980s and yet the problem of global warming has not been effectively addressed. What are the challenges responsible for this state of affairs? It is this question that is now being addressed below.

\subsection{Challenges}

One of the factors responsible for this state of affairs is not unconnected with national interest ideology of nation states for instance as played out during the RIO Earth summit of 1992 when America refused to sign some Declarations of the summit. Along the same direction, pledges that were made at public fora to contribute significantly to the amelioration of global warming are often not redeemed due to national interest mind set. For instance, the United Nations Summit 112002 in Johannesburg is about environment and development issues in public arena and the leaders at the conference committed themselves to

- Building a human, equitable and caring global society;

- A collective responsibility to advance and strengthen the interdependent and mutually reinforcing pillars of sustainable development - economics, social development and environmental protection at the local, national, regional and global levels; and

- Common resolve to produce a practical and visible plan that should bring about poverty eradication and human development.

In concrete terms, United States pledged to invest $\$ 970$ million over the next three years on water sanitation projects and \$43 million on sustainable energy projects in developing countries in 2003; and $\$ 2.3$ billion through 2003 on health programs. It pledged $\$ 90$ million for sustainable agricultural program in 2004 and a further commitment to spend \$53 million on forests in 2003-2005. The European Union made similar financial commitments on water, sanitation, energy and health projects in the states of the South. Norway pledged an additional \$50million towards following the Johannesburg commitments. The United Kingdom announced it was doubling its assistance to Africa by £1billion a year and raising its overall assistance for all countries by $50 \%$. The EU announced that it would increase its development assistance with more than £22billion until 2006 and more than £9billion annually from 2006 onwards.

Germany announced the contribution of £500million over the next 5years to promote cooperation on renewable energy. Canada announced that, as of $1^{\text {st }}$ of January 2003, it would eliminate tariff and quotas on almost all products from the least developed countries and that by 2010, it would double development assistance.

Japan announced that it would provide at least $¥ 250$ billion in education assistance over a five-year period. Ireland announced that it has allocated £8million in emergency funding in response to humanitarian needs of African region. Are these pledges redeemed?

Another challenge emerges from the lack of development of the developing countries. Poverty in these 
countries makes them incapacitated to make meaningful contribution to international problems. A few become involved in regional problems but in general, they are really subjects of international politics, that is, being part of international problems. The challenge before the global community is how to build capacity in these countries so that they can really be part of solutions to global problems.

Furthermore, another challenge before the global community is to articulate the nature of the problems inherent in searching for low carbon society. The problem of global warming leading to climate change but demanding for solution is uniquely different from the previous global problems like poverty, refuge, nuclear warfare, economic regional disparity and its difficulties, etc. The reality of climate change which is a symbol of environmental degradation and the catastrophic nature of its consequences (The possibility of the collapse of the ecosystem could not be ruled out), marks it out as the contemporary global problem. The project of low carbon society involves every nation and its realization cannot be delayed. Any delay in addressing the issue promptly and radically too may mean that the entire humanity may 'sink' sooner than later! This message is yet to be taken seriously by the international community in its activities nationally and internationally.

Another challenge to effectively tackle global warming is that of the weakness of enforcement mechanism of compliance with international law. In the light of major actors in international system not respecting their pledges and abiding with international environmental laws and protocols what is the way forward in developing low carbon societies especially in the developing countries as they will account for more than half of the global population and GHG emissions by 2050. This is now addressed under the way forward

\subsection{Way Forward}

The following may constitute the way forward.

\subsubsection{Necessity of Reconstruction of Ideological Mind- Set of National Interest of Nation States}

An ideology is a set of conscious and unconscious ideas that constitute one's goals, expectations, and actions. It can also be described as a comprehensive vision, a way of looking at things (compare worldview) as in several philosophical tendencies, or a set of ideas proposed by the dominant class of a society to all members of this society (a "received consciousness" or product of socialization.

Furthermore, ideologies can be seen as systems of abstract thought applied to public matters and thus make this concept central to politics. Implicitly every political or economic tendency entails an ideology whether or not it is propounded as an explicit system of thought [19].

Accordingly, many political parties base their political actions and programs on an ideology. In that context, their political ideology entails to some certain ethical set of ideals, principles, doctrines, myths, or symbols of a social movement, institution, class, or large group that explains how society should work, and offers some political and cultural blueprint for a certain social order. A political ideology largely concerns itself with how to allocate power and to what ends it should be used. Some parties follow a certain ideology very closely, while others may take broad inspiration from a group of related ideologies without specifically embracing any one of them.

Political ideologies have two dimensions namely goals, that is, how society should work and methods, that is, the most appropriate ways to achieve the ideal arrangement. Typically, each political ideology contains certain ideas on what it considers to be the best form of government (e.g. democracy, theocracy, caliphate etc.), and the best economic system (e.g. capitalism, socialism, mixed economy, etc.). Ideologies also identify themselves by their position on the political spectrum (such as the left, the center or the right), though this is very often controversial. Ideologies can be distinguished from political strategies (e.g. populism) and from single issues that a party may be built around.

Political ideologies are concerned with many different aspects of a society, some of which are the economy, education, health care, labour law, criminal law, the justice system, the provision of social security and social welfare, trade, the environment, minors, immigration, race, use of the military, patriotism, and established religion.

Flowing from ideology national interest becomes the raison d'état of the existence of the state in the first instance. The notion of the national interest has dominated European politics that became fiercely competitive since the seventeenth century. It is a form of reason "born of the calculation and the ruse of men" and makes of the state "a knowing machine, a work of reason." The state ceases to be derived from the divine order and is henceforth subject to its own particular necessities. States could now openly embark on wars purely out of self-interest.

With this basic understanding of ideology and national state interest, it may be argued that every nation state can accommodate anything and everything can be appropriated to become national interest. Given the challenges of global warming, maintaining a low carbon society could be targeted as the national interest of states both in domestic and international politics. With hegemonic stability theory, the concept of the U.S. national interest was expanded to include the maintenance of open sea lanes and the maintenance and expansion of free trade. Since national interests have been the guiding principles of states' relations, and states tend to appropriate resources to its achievement for the 'betterment of the states and its people', it then means that achieving low carbon society must be pursued within the orbit of national interest for the good of states both internally and externally. Therefore every national state may be persuaded to embrace those projects that will benefit humanity such as the project of low carbon society as its national interest. The second recommendation has to do with the necessity for the reform of the United Nations from an African perspective.

\subsubsection{The Necessity for the Reform of the UN from an African Perspective}

History of the world witnessed slave trade, the practice of divine right of kings in Europe, loss of Papal Universal Sovereign right, enthronement of human rights and democracy. In the same vein, women can now become head of state and hold any political or professional posts. Hitherto, when the beneficiaries of the status quo of the respective past eras were expected to change their situation so that the generality of people might have a 
better and improved standard of living, they refused because of the fear and consequences of change. At the appropriate time due to variety of circumstances new reality was borne to replace the old regime. Business as usual had to stop and the world could become a better place for it and especially the cherished values of democracy and good governance that are being nurtured will promote the well-being of humanity.

Ironically, the UN, the symbol of international community has resisted being thoroughly democratic. In the UN proposed reform, the members of the Security Council have no problems with all areas needing reform except the areas of veto power and the expansion of the Security Council. Unfortunately these are the core of the desired reform. Giving the constitutional framework of the UN without the cooperation of the members of the Security Council, the necessary comprehensive UN reform may not see the light of day. Therefore the members of the UNSC could be persuaded, in the name of humanity, democracy, global problems to have a change of heart and embrace comprehensive reform UN requires at this point of its existence. In order that its pronouncements to become truly universal and biding especially in respect of global problems, it has to be democratic and undergo necessary reform [20]. From an African perspective, the reform of the UN may include

1. Membership is to be limited to democratic countries with proven human rights and environmental justice;

2. Article 2.7 of the Charter which prohibits the UN from intervening 'in matters which are essentially within the jurisdiction of any state' must be modified to reflect the need for humanitarian intervention;

3. NGOs and civil society are to be represented at the activities and major decisions of the UN system;

4. The Secretary-General who enjoys a seven year term only should cease to be one who simply takes instructions from the General Assembly and the Security Council. The Secretary-General should enjoy some authority similar to that of a prime minister or president of a state;

5. Training and promotion of staff should be standard, and race and gender balance should be pursued. The economic and social agencies in particular must go back to their original mandates as intellectual clearing-houses. Some agencies may be abolished some amalgamated and others have their mandates renewed. All the UN agencies are to come under the oversight and co-ordination of the Secretary-General and enjoy common management, financial and staffing procedures;

6 . The scale of assessments of the contribution of the members should reflect the fact that countries that have become richer must pay proportionally, although a maximum ceiling ought to be established for all, and fixing minimum rate of assessment must take into account the ability of the very poor countries;

7. Machinery reform of the UN System must be updated. Like any business organization in particular where the services of outside consultants are engaged whenever there is a need for a radical reorganization changes, the UN system must adapt its procedures and need to consider the views of all member states to pursue reform; and
8. Expansion of the Security Council to reflect regional identities of members of the UN and that the veto of permanent members be suppressed and their responsibilities be reviewed to reflect democratization, human rights provisions, economic and environmental justice.

Another area of concern as a way forward is that of the rule of law at the international level of nation states' interactions.

\subsubsection{Necessity of the Commitment to the Rule of Law at International Level of Interactions}

Commitment to the rule of law of International Law under the socio economic politics of nation states' relations in their duties and rights was arguably established in 1648 at the Treaty of Westphalia. The treaty stripped political authority from the Pope, Monarchs, Dukes, and Duchess and made the state the cornerstone of modern state system. On the foundation of Hugo Grotius's On the Law and Peace, the eighteenth, nineteenth and twentieth century states built an imposing edifice of international law consisting of thousands of treaties, and hundreds of decisions of international tribunals, and innumerable decisions of domestic courts. These treaties and decisions were established to regulate the multiple international contacts with resultant effect on modern communications, international exchange of goods and services, and the uncountable number of international institutions which other states in one way or the other have co-operated with in furtherance of their national interests. Some of these institutions are the Red Cross, United Nations Educational, Scientific and Cultural Organization (UNESCO), World Health Organization (WHO) and International Labor Organization (ILO) [21].

States create International Law as a way to influence behavior, avoid conflict and maintain peace and cooperation. International law is to lead to enhancing the stability of international peace, to the protection of the rights of human and to reducing the evils and abuses of national power [22].

The rules and principles of international law are increasingly important to the functioning of interdependent world. The growth of human rights law and the establishment of a permanent war crimes court to hold rulers accountable for their policies toward citizens have built confidence that a true world of law will emerge with greater institutional support than in the past. This implies that the down of this millennium brings greater recognition, of the reality and relevance of international law than in the past. However, the need to surmount the fundamental obstacle of self-serving, sovereign state interests remains the pre-eminent challenge on international law's global agenda in this century.

For the United Nations, without enforceable International Law, there could be chaos. International Law sets up a framework based on States as the principal actors in the international legal system, and within States boundaries, with their treatment of individuals. Its domain encompasses human rights, disarmament, international crime, refugees, migration, nationality problems, treatment of prisoners, the use of force, and the conduct of war, among others. It also regulates the global commons such as international waters, outer space, arctic and Antarctic circles and heritage sites. World trade and global 
economy depend on it as it regulates the activities required to conduct business across borders such as financial transactions and transportations of goods. There are treaties for roads, highways, railways civil aviation, bodies of water and access to shipping for States that are landlocked.

International Law helps to monitor and regulate the relationship between states and international entities. Increasingly, parties are submitting disputes arising out of international contracts to arbitration. While this is true for general commercial contracts, it is a particularly marked trend in the construction, energy and investment dispute areas [23].

As international human rights law developed, a number of UN human rights bodies were established to respond to evolving human rights challenges. These bodies which rely on the High Commissioner's Office for substantive and secretariat support, can be either Charter-based (political bodies composed of the states' representatives, with mandates established by the UN Charter) or treatybased (committees composed of independent experts, established by international human rights treaties and mandated to monitor states Parties' compliance with their treaty obligations). The United Nations Commission on Human Rights which was established in 1946 and reported to the Economic and Social Council was the key United Nations inter-governmental body responsible for human rights until it was replaced by the Human Rights Council in 2006. In addition to assuming the mandates and responsibilities previously entrusted to the Commission, the Council reports and recommends to the General Assembly ways of further developing international human rights law. Two years after its first session the Council operationalised the newest international human rights mechanism, the Universal Periodic Review.

While it does not stand as a treaty per se, the Universal Periodic Review Declaration was explicitly adopted for the purpose of defining the meaning of the words 'fundamental freedoms' and 'human rights' appearing in the United Nations Charter which is binding on all member states. For this reason the United Nations Universal Declaration of Human Rights is a fundamental constitutive document of the United Nations. Many international lawyers, in addition, believe that the Declaration forms part of customary international law and is a powerful tool in applying diplomatic and moral pressure to governments that violate any of its articles. The 1968 United Nations International Conference on Human Rights advised that it 'constitutes an obligation for the members of the international community' to all persons. The Declaration has served as the foundation for two binding UN human rights covenants, the International Covenant on Civil and Political Rights, and the International Covenant on Economic, Social and Cultural Rights and the principles of the Declaration are elaborated in international treaties such as the International Convention on the Elimination of All Forms of Racial Discrimination, the International Convention on the Elimination of Discrimination Against Women, the United Nations Convention on the Rights of the Child, the United Nations Convention against Torture and many more. The Declaration continues to be widely cited by governments, academics, advocates and constitutional courts and individual human rights who appeal to its principles for the protection of their recognized human rights.

The human rights regime suggests that there may be some actions such as torture, slavery and arbitrary detention that are prohibited regardless of their statutes in domestic law and regardless of the official statues of the perpetrator. The enforcement of this position is a severe challenge to the notion of the sovereign state and to the 'sovereign immunity' from prosecution conventionally enjoyed by heads of state and other state officials.

In the international sphere, necessity and mutual consent are the operating forces in the creation and enforcement of a law. This is why morality plays a vital role on the conduct of states because the notion of moral behavior may be linked to religious beliefs, secular ideologies or philosophies, the standard of equity (that is, what is fair, and as well as the practice of a society, that is, what a society considers moral behavior. Sometimes this becomes law and vice versa, legal standards most times are adopted by a society as moral standards).

Despite the advantage and potentials of international law to contribute positively to security, stability and progress of the world, unfortunately many of these treaties and international laws are being violated especially when there is a clash of interest between national and international interests. In all, it may be affirmed that international politics is not unimpeded by 'politics of deceit and blatant lies' where many nation states are not sincere in redeeming the pledges of their commitment and upholding the value of common good for the sake of humanity. For instance, early 1998, in his Presidential Directives, the US President Bill Clinton affirmed that his country would use nuclear weapons on any country should the US national interest dictate. This pronouncement is coming from the backdrop of the 1968 Non-Proliferation Treaty where countries that did not have nuclear weapons were persuaded not to seek to acquire the capability of nuclear nation state. The Treaty guaranteed security to those countries without nuclear weapons and had not expressed interest in having one. For the US President, two decades later to make such a pronouncement is rather unfortunate. Politics of this type cannot promote cooperation and guarantee true security globally. There must be a way out for international laws to be binding on all members of international community. Another way forward is the renewal of international ethics (morality).

\subsubsection{Necessity for the Renewal of International Ethics (Morality)}

Ethics may be described as 'the study of the concepts involved in practical reasoning: good, right, duty, obligation, virtue, freedom, rationality, choice' [24]. In philosophy, ethics studies the moral behaviour in humans and how one should act. Ethics may be divided into four major areas of study. These are

- Meta-ethics, about the theoretical meaning and reference of moral propositions and how their truth values (if any) may be determined;

- Normative ethics, about the practical means of determining a moral course of action;

- Applied ethics, about how moral outcomes can be achieved in specific situations;

- Descriptive ethics, also known as comparative ethics, is the study of people's beliefs about morality; 
In general ethics seeks to resolve questions dealing with human morality especially in relation to concepts such as good and evil, right and wrong, virtue and vice, justice and crime. Here the two main areas of consideration are normative and applied ethics.

Traditionally, normative ethics (also known as moral theory) was the study of what makes actions right and wrong. These theories offered an overarching moral principle one could appeal to in resolving difficult moral decisions.

At the turn of the 20th century, moral theories became more complex and are no longer concerned solely with rightness and wrongness, but are interested in many different kinds of moral status. During the middle of the century, the study of normative ethics declined as metaethics grew in prominence. This focus on meta-ethics was in part caused by an intense linguistic focus in analytic philosophy and by the popularity of logical positivism.

From modern ethics emerged consequentialism. Consequentialism refers to moral theories that hold that the consequences of a particular action form the basis for any valid moral judgment about that action (or creates a structure for judgment). Thus, from a consequentialist standpoint, a morally right action is one that produces a good outcome, or consequence. This view is often expressed as the aphorism "The ends justify the means".

The defining feature of consequentialist moral theories is the weight given to the consequences in evaluating the rightness and wrongness of actions. In consequentialist theories, the consequences of an action or rule generally outweigh other considerations. Apart from this basic outline, there is little else that can be unequivocally said about consequentialism as such. One way to divide various consequentialisms is by the types of consequences that are taken to matter most, that is, which consequences count as good states of affairs.

According to hedonistic utilitarianism, a good action is one that results in an increase in pleasure, and the best action is one that results in the most pleasure for the greatest number. Closely related is eudaimonic consequentialism, according to which a full, flourishing life, which may or may not be the same as enjoying a great deal of pleasure, is the ultimate aim. Similarly, one might adopt an aesthetic consequentialism, in which the ultimate aim is to produce beauty. However, one might fix on non-psychological goods as the relevant effect. Thus, one might pursue an increase in material equality or political liberty instead of something like the more ephemeral "pleasure". Other theories adopt a package of several goods, all to be promoted equally. Whether a particular consequentialist theory focuses on a single good or many, conflicts and tensions between different good states of affairs are to be expected and must be adjudicated.

Utilitarianism is a hedonistic ethical theory that argues the proper course of action is one that maximizes overall "happiness". Jeremy Bentham and John Stuart Mill are influential proponents of this school of thought. In $A$ Fragment on Government Bentham says 'it is the greatest happiness of the greatest number that is the measure of right and wrong' and describes this as a fundamental axiom. In An Introduction to the Principles of Morals and Legislation he talks of 'the principle of utility' but later prefers "the greatest happiness principle.
Hedonistic utilitarianism is the paradigmatic example of a consequentialist moral theory. This form of utilitarianism holds that what matters is the aggregate happiness; the happiness of everyone and not the happiness of any particular person. John Stuart Mill, in his exposition of hedonistic utilitarianism, proposed a hierarchy of pleasures, meaning that the pursuit of certain kinds of pleasure is more highly valued than the pursuit of other pleasures. That notwithstanding, there are some questions that many consequentialist theories need to address:

- What sort of consequences count as good consequences?

- Who is the primary beneficiary of moral action?

- How are the consequences judged and who judges them?

Deontological ethics or deontology (from Greek déov,

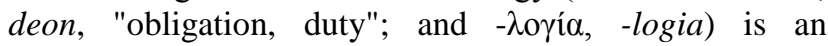
approach to ethics that determines goodness or rightness from examining acts, or the rules and duties that the person doing the act strove to fulfil. This is in contrast to consequentialism, in which rightness is based on the consequences of an act, and not the act by itself. In deontology, an act may be considered right even if the act produces a bad consequence, if it follows the rule that "one should do unto others as they would have done unto them" and even if the person who does the act lacks virtue and had a bad intention in doing the act. According to deontology, we have a duty to act in a way that does those things that are inherently good as acts ("truth-telling" for example), or follow an objectively obligatory rule (as in rule utilitarianism). For deontologists, the ends or consequences of our actions are not important in and of themselves, and so is our intentions are not important in and of themselves.

Immanuel Kant's theory of ethics is considered deontological for several different reasons-First, Kant argues that to act in the morally right way, people must act from the view point of duty (deon). Second, Kant argued that it was not the consequences of actions that make them right or wrong but the motives (maxime) of the person who carries out the action.

Kant's argument that to act in the morally right way, one must act from duty, begins with an argument that the highest good must be both good in itself, and good without qualification. Something is 'good in itself' when it is intrinsically good, and 'good without qualification' when the addition of that thing never makes a situation ethically worse. Kant then argues that those things that are usually thought to be good, such as intelligence, perseverance and pleasure, fail to be either intrinsically good or good without qualification. Pleasure, for example, appears not to be good without qualification, because when people take pleasure in watching someone suffering; this seems to make the situation ethically worse. He concludes that there is only one thing that is truly good:

Nothing in the world-indeed nothing even beyond the world-can possibly be conceived which could be called good without qualification except a good will.

Post-structuralism and postmodernism argue that ethics must study the complex and relational conditions of actions. A simple alignment of ideas of right and particular acts is not possible. There will always be an ethical remainder that cannot be taken into account or 
often even recognized. Such theorists find narrative (or, following Nietzsche and Foucault, genealogy) to be a helpful tool for understanding ethics because narrative is always about particular lived experiences in all their complexity rather than the assignment of an idea or norm to separate and individuated actions.

This above very simple general overview of ethics exposes the complex nature of ethics. For religious persons the metaphysical cum transcendental dimension of reality must have a place. Until a satisfactory ethical regime is established, the principles of Human Rights Declaration in all its ramifications can be relied upon in interstate international system interactions. Good governance especially in African countries is another area of concern as a way forward.

\subsubsection{Necessity for Good Governance of the African Countries}

Governance is the act of governing. It relates to decisions that define expectations, grant power, or verify performance. It consists of either a separate process or part of decision-making or leadership processes. In modern nation-states, these processes and systems are typically administered by a government.

When discussing governance in particular organisations, the quality of governance within the organisation is often compared to a standard of good governance. Good governance has eight major characteristics. It is participatory, consensus oriented, accountable, transparent, responsive, effective and efficient, equitable and inclusive and follows the rule of law. It assures that corruption is minimized, the views of minorities are taken into account and that the voices of the most vulnerable in society are heard in decision-making. It is also responsive to the present and future needs of society.

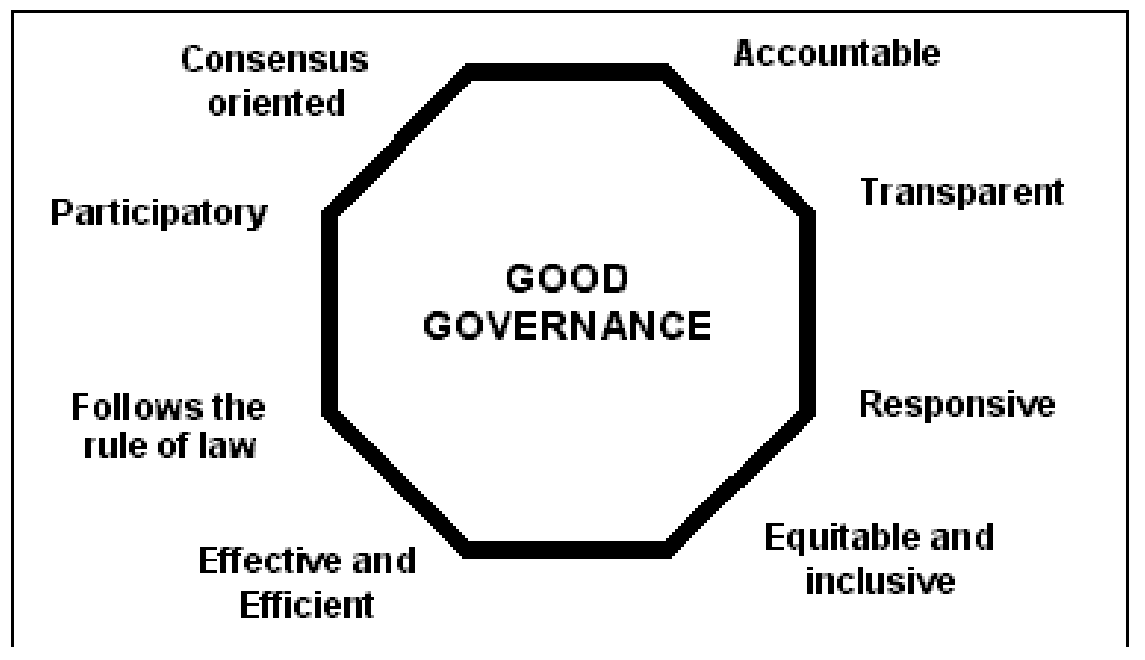

Figure 1. Characteristics of good governance (Source: Wikipedia, accessed by July 25, 2013)

Measuring governance is inherently a controversial and political exercise. There is no one way. However, in the African countries context three distinctions can be made namely, external assessments, peer assessments and selfassessments. Examples of external assessments are donor assessments or comparative indices produced by international non-governmental organisations. An example of a peer assessment is the African Peer Review Mechanism. Examples of self-assessments are country-led assessments that can be led by government, civil society, researchers and/or other stakeholders at the national level.

One of these efforts to create an internationally comparable measure of governance and an example of an external assessment is the Worldwide Governance Indicators Project, developed by members of the World Bank and the World Bank Institute. The project reports aggregate and individual indicators for more than 200 countries for six dimensions of governance: voice and accountability, political stability and lack of violence, government effectiveness, regulatory quality, rule of law, control of corruption. To complement the macro-level cross-country Worldwide Governance Indicators, the World Bank Institute developed the World Bank Governance Surveys, which are country-level governance assessment tools that operate at the micro or sub-national level and use information gathered from a country's own citizens, business people and public sector workers to diagnose governance vulnerabilities and suggest concrete approaches for fighting corruption.

A new World Governance Index (WGI) has been developed and is open for improvement through public participation. The following domains, in the form of indicators and composite indexes, were selected to achieve the development of the WGI: Peace and Security, Rule of Law, Human Rights and Participation, Sustainable Development, and Human Development.

Additionally, in 2009 the Bertelsmann Foundation published the Sustainable Governance Indicators (SGI), which systematically measures the need for reform and the capacity for reform within the Organisation for Economic Co-operation and Development (OECD) countries. The project examines to what extent governments can identify, formulate and implement effective reforms that render a society well-equipped to meet future challenges, and ensure their future viability (The above discourse on development index, etc. are well captured [25]. Examples of country-led assessments include the Indonesian Democracy Index, monitoring of the Millennium Development Goal 9 on Human Rights and Democratic Governance in Mongolia and the Gross National Happiness Index in Bhutan.

Participatory governance focuses on deepening democratic engagement through the participation of citizens in the processes of governance with the state. The 
idea is that citizens should play direct roles in public decision-making or at least engage more deeply with political issues. Government officials should also be responsive to this kind of engagement. In practice, participatory governance can supplement the roles of citizens as voters or as watchdogs through more direct forms of involvement.

From the above, it should be clear that good governance is an ideal which is difficult to achieve in its totality. Very few countries and societies have come close to achieving good governance in its totality. However, to ensure sustainable human development, actions must be taken to work towards this ideal with the aim of making it a reality. African countries have a long way to go. Until African countries are characterised with the good governance as outlined above they may not be able to contribute meaningfully to the project of low carbon society.

\section{Concluding Remarks}

Variety of negative human activities has polluted marine, land, air and atmospheric spaces leading to global warming and consequently treating the carrying capacity of the planet. The polluting activities of human are primarily anchored on the national interest ideology and violation of the first principle of the Rio Earth Summit Declaration on Environment and Development namely: Human beings are at the center of concerns for sustainable development. They are entitled to a healthy and productive life in harmony with nature. Compounding this reality is the uncertainty, on enforceable and lack of a centralized and hierarchical lawmaker akin to the legislature of municipal law to specify authoritative sources of law and the mechanism of legal change and reconciliation of international law. It also lacks centralized and hierarchical judicial institutions [26] to resolve the resulting legal uncertainty in 'a peaceful universe in an age of uncertainty' [27]. As a result, its norms are imprecise, contested, internally contradictory, overlapping and subject to multiple interpretations and claims. In spite of this deficiency, the rules and principles of international law are increasingly gaining recognition and becoming important to the functioning of interdependent world and symbiotic relationship of its principal actors and constituency of human and planet Earth.

The absence of a central authority does not in any way make the international system synonymous with anarchy. Ordinarily, the absence of an executive authority in the international system means that states and non state actors would have to rely on their own resources and power for the achievement of their individual and corporate interests. In so far as the interest at state level is perceived as vital or core, the states in the international system may have to devise various means including military action/use of force to achieve those interests.

While the international system may be characterized by the situation of conflicts, there are also situations of cooperation particularly the contemporary international political system is characterized by high degree of interdependence especially in the economic sphere. Today unlike in the $19^{\text {th }}$ century system, states are no longer selfsufficient and impermeable entities, especially in the economic terrain as all states now cooperate economically (either in search of raw-materials, resources, new technologies) for their domestic economic survival. Nonetheless, the structure of the international system means that every state (in its cooperative situation) tends to pursue its own interest and to maintain its survival and that of its citizens.

It may therefore be concluded that the way forward is for the international community to unanimously address credibly and creatively the challenges of symbiotic relationships of national interest ideology, issue of putting human beings at the heart of political and socio-economic activities of global world and the project of low carbon society within the context of international law. Similarly, reform of United Nations Security Council needs to be taken seriously as President Good Luck Jonathan timely called for at the $68^{\text {th }}$ UN General Assembly of September 2013.

Mr. President, I believe that I express the concern of many about the slow pace of effort and apparent lack of progress in the reform of the United Nations, especially the Security Council. We believe strongly, that the call for democratization worldwide should not be for States only, but also, for International Organizations such as the UN. That is why we call for the democratization of the Security Council.

This is desirable for the enthronement of justice, equity, and fairness; and also for the promotion of a sense of inclusiveness and balance in our world' [28].

Attention to these among others would help international community to purposefully address issue of low carbon society for sustainable development of the countries of the world. In addition, it may be affirmed that without good governance locally and globally, the objective of creating and maintaining low carbon society will remain a mirage.

\section{References}

[1] Holsti, K. J. (1977) ( $3^{\text {rd }}$ edn.) International Politics: A Framework for Analysis Prentice-Hall, New Jersey, p.73 and Rourke, J and Boyer M, (2004) International Politics on the World State ( $5^{\text {th }}$ edn.), Mcgraw-Hill Companies, New York: 399.

[2] Gross, L. (1948), "The Peace of Westphalia", The American Journal of International Law 42 (1): 20-41.

[3] Osiander, A. (2001), "Sovereignty, International Relations, and the Westphalian Myth", International Organization 55 (2): 251-287.

[4] Frankel, Joseph (1973), Contemporary Theory and the Behaviour of States, Oxford University Press, Oxford.

[5] Mongenthau, H. J. (1967) Politics Among Nations: The Struggle for Power and Peace, $4^{\text {th }}$ edn. Knopf, New York, pp. 106-43.

[6] Goldstein J.S. and Povehouse, J.C., (2011) 9edn. International Relations, Longman, Boston, pp. 416-147, 429-31 quoting UNFPA data, UN State of World Population Report 2004 and Bolton, G. (2007) Africa Doesn't Matter: How the West Has Failed the Poorest Continent and What we can Do About it, Arcade Publishing, New York, pp. 289-322.

[7] Olaniyan, R. O, The New International Economic Order (NIEO): A Review, Nigerian Forum, March 1987, Nos. 3\&4.

[8] US Environmental Protection Agency (1987) National Air Quality and Emissions Trend Report 1985.US EPA Research, Triangle Park, North Carolina.

[9] Simarski, L. T. \& Bush, S. (1991) Congress Probes Climatic Change Uncertainties. EOS, Transactions of American Geophysical Union, 72(43); 465-466.

[10] Major, S. (1989) The Ozone Layer: Facts and Figures You Need to Know. Ideal Home, 137 (4).

[11] United Nations Environmental Program, (1987) The Changing Atmosphere: Environmental Brief No. 1. 
[12] Wikipedia, accessed July, 25, 2013.

[13] Simonis, U. I., (2007) 'Kyoto 11 and Houston Protocol' On the Future of International Climate Policy being a lecture at the $12^{\text {th }}$ Japanese-German Symposium: A Universal challenge May 12, 2007 in Bamberg p. 10.

[14] Rodda, A. (ed) (1991) Women and the Environment, Zed Books, London, p, 13; Houghton, J., (1994) Global Warming, Lion Publishing, Oxford, p. 93-96 and Foley, G. (1991) Global Warming, Panos Publication Ltd, London, p. 41.

[15] Wikipedia, accessed July, 25, 2013.

[16] McDonagh, S (1999) Greening the Christian Millennium, Dominican Publication, Dublin, p. 86.

[17] Oyeshola, D (1995) Essentials of Environmental Issues: The World and Nigeria in Perspective, Daily Graphics, Ibadan, p. 13; Oyeshola, D., (1998) Politics of International Environmental Regulations, Daily Graphics, Ibadan, p. 51 and Adinna, E.N. (2001) Environmental Hazards and Management, Snaap Press, Enugu.

[18] Wikipedia, accessed July, 25, 2013.

[19] Wikipedia, accessed July, 25, 2013.

[20] (Oyeshola, D., (2009)'UN Reform and the Role of the Security Council: The Imperative of Democratic Governance from an African Perspective' in Alexander, K. (ed) (2009) Terrorism and Global Insecurity: A Multidisciplinary Perspective, Linton Atlantic Books, Yarnton, Oxon (UK), Cambridge (UK) pp. 245260.

[21] Shaw, M.N. (1998) International Law (4 ${ }^{\text {th }}$ edn.) Cambridge University Press, Cambridge, p. 21-27.

[22] Shaw, M.N. (1998) International Law (4 ${ }^{\text {th }}$ edn.) Cambridge University Press, Cambridge, p. 21-27.
[23] Blackburn, S. (1994) The Oxford Dictionary of Philosophy, Oxford University Press, Oxford, p. 126.

[24] Wiki encyclopaedia, accessed by July 25, 2013

[25] Haq, M. U. (1995) Reflections on Human Development, Oxford University Press, Oxford; Haq, M. (1995) Human Development Report, 2007-2008. www.undp.org/hdr; Human Development Report 2007-2008. www.undp.org/hdr; Ikejiaku, B. (2009). The Relationship between Poverty, Conflict and Development. Journal of Sustainable Development, Vol. 2, No. 1, March 2009; Geismar, $\mathrm{T}$ and AIGA (2007) Measuring Human Development: A Primer guidelines and tools for statistical research, analysis and advocacy, conceived by Tom Geismar and developed by AIGA, the professional association for design, as part of the launch strategy of the 2005 global Human Development Report, September 2007, New York; Journal on World Development Vol. 35, No. 7: 12591276, 2007; Journal of International Development 10, 589-605 (1998), Calculating the Human Development Indices, Technical note 1. HDR 2007-2008 and Udoji, A.E (2006) The Effects of Nigeria's Membership of the World Trade Organization (WTO) on the Textile Industry in Nigeria, M.Sc. Thesis submitted to the Department of International Relations, Obafemi Awolowo University, Ile-Ife.

[26] Shaw, M.N. (1998) International Law (4 ${ }^{\text {th }}$ edn.) Cambridge University Press, Cambridge, p. 3.

[27] Goodluck Jonathan, 'Terrorism a major threat to global peace', The Nation, Lagos, 26 September, 2013. p. 64.

[28] Goodluck Jonathan, 'President Goodluck Jonathan's Speech at the United Nations General Assembly on Tuesday', The Nation, Lagos, September 26, 2013, p. 64. 